\section{Pawel Bukowiec}

Jagiellonian University in Kraków

\title{
World Literature as a Non-Place ${ }^{1}$
}

\begin{abstract}
This paper is an attempt at alter-globalist criticism of the contemporary discourse of world literature from the perspective of a researcher of two small European literatures (namely, Polish and Lithuanian). Beginning with classical definitions, the study analyses concrete proposals of the canon of world literature in order to indicate its violent character and prove the existence of the principle of "spoilage" of information inscribed in the criticised discourse.
\end{abstract}

Keywords: world literature, literatures of the world, literary canon, cultural diversity.

\section{Two definitions, one literature}

At the beginning of the fourteenth century, Dante made Ulysses suffer in the fire of the eighth circle of Hell for, among other things, boldly breaking the limits of the world available to men, for going beyond the Pillars

1 This work has been supported by the Polish National Science Center (NCN) within the project "Lithuanian-Polish Literary Bilingualism in Years 1795-1918" (Project No. 2013/09/B/HS2/01206). Some of the considerations contained in this text were presented at the conference "Perspectives of Baltic Philology IV", organised by Adam Mickiewicz University in Poznań. 
of Hercules. ${ }^{2}$ Why did the conqueror of Troy do this? According to the condemned man himself: "to be experienced of the world"3 (in original: "divenir del mondo esperto", Inf. XXVI, 984). More than 500 years later, Phileas Fogg in Jules Verne's novel, albeit much less bold than Ulysses, experienced the world to circling the entire globe successfully in eighty days ${ }^{5}$ and paying for it only with big money, not with his life (the expedition cost 20,000 pounds at that time, which is roughly equivalent to 2 million pounds today ${ }^{6}$ ). The next 250 years have passed and today each of us can repeat this feat in about fifty hours, flying across the Earth, taking, for example, the route LondonMumbai-Tokyo-LA- London. ${ }^{7}$ The price for this experiment will be neither eternal condemnation, nor tremendous expense, but the modest sum of 1,000 to 1,500 dollars and a transient sense of tiredness. "A whole world in Your hands", like in the classic Mastercard commercial?" And per analogy: A whole literature of the world in Your hands? A whole world literature in Your hands? What kind of economy of meanings makes us construct such metonymic figures of the whole?

The concept of world literature (Ch.M. Wieland's and, above all, J.W. Goethe's Weltiteratur) is only slightly older than Jules Verne. I think that it could not have come into being earlier. For example, it is far too weak for Dante's reductionist universalism, in whose architectural system everything comes down to the one and only God. This is much unlike Phileas Fogg: for him, everything comes down to Europe, and this is why his journey can be regarded as a peculiar figure of world literature, successfully exposing the evident Eurocentrism that underlies the style of thinking that gave birth to both ideas, that is, the journey around the world and world literature. The whole world is now available in its unreducible multiplicity, even if still at the cost of a huge effort (organisational, cognitive, physical) undertaken by a European in the name of European values (especially a gentleman's honour). This whole is also interest-

2 See: O. Lagercrantz, Odysseus, in: idem, Från helvetet till paradiset: En bok om Dante och hans komedii, Stockholm 1964, pp. 64-76. I also used the Polish translation: O. Lagercrantz, Odyseusz, in: idem, Od piekiet do raju: Dante i „Boska Komedia”, transl. A.M. Linke, Warszawa 1970, pp. 60-71.

3 D. Alighieri, The Divine Comedy. Inferno, transl. H.W. Longfellow, p. 174, https:// wyomingcatholic.edu/wp-content/uploads/dante-01-inferno.pdf (access: 12.08.2019). Emphasis-P.B.

4 D. Alighieri, La Divina Comedia, a cura di T. Di Salvo, Bologna 1991, p. 444.

5 J. Verne, Le tour du monde en quatre-vingts jours, Paris [1874].

6 Inflation calculator available on https://bankofengland.co.uk/monetary-policy/inflation (access: 12.08.2019).

7 It is a route that coincides approximately with the course of the Fogg's escapade, cf. J. Verne, op.cit., map after p. 217.

8 See: https://youtube.com/watch?v=zT8cOuLgU30 (access: 12.08.2019). Emphasis-P.B. 
ing because of contrast. The old good Europe remains the unwavering centre of the world: behold the man - because Europe is a man! — who is the point of departure and arrival, the source of money, knowledge, and morality. There is a characteristic exchange between Fogg and the world, painfully visible in the relationship between Phileas (male Europe) and Aouda (the female rest of the world, passive and at the most instinctively noble): she gives him an exotic experience and masculine fulfilment, he gives her European humanity and the feminine sense of belonging.

Is the concept of world literature useful today? Is the Eurocentric heritage of Goethe-Verne-Fogg inscribed in it not anachronistic at a time when eighty days have shrunk to two, two million pounds to several hundred dollars, Europe has ceased to be the only centre and, to crown it all, the very concept of centre has inevitably lost its innocence? These questions are all the more important as we are talking not only about the research perspective, but also about pedagogical practice; world literature is often one of the courses in the programme of literary studies, a block of courses, and even a whole curriculum.

Among the many definitions of world literature-which, after all, has been a subject of intense exploration for the past several decades - there are two most important for the purposes of this text, namely those written by David Damrosch and Franco Moretti:

World literature is an elliptical refraction of national literatures. World literature is writing that gains in translation. World literature is not a set canon of texts but a mode of reading: a form of detached engagement with worlds beyond our own place and time. ${ }^{9}$

World literature is $[\ldots]$ one, and unequal: with a core, and a periphery $[\ldots]$ that are bound together in a relationship of growing inequality. One, and unequal: one literature (Weltliteratur), or perhaps, better, one world literary system (of inter-related literatures); $[\ldots]$ a system, which is $[\ldots]$ profoundly unequal. ${ }^{10}$

Both quoted definitions come from the turn of the twenty-first century. They are very different. The former was formulated by the classic figure of research on world literature, the latter as a bywork, as it were, of constructing the methodology of research on the world novel. The former is a product of thinking of an openly hermeneutical nature, the latter is based on a clearly visible structuralist impulse. What is most important, the former is based on close reading and sensitivity to the sense-creating changeability of the context, the latter is based on a controversial assumption of non-reading,

9 D. Damrosch, What Is World Literature?, Princeton, NJ 2003, p. 281.

10 F. Moretti, Conjectures on World Literatures, in: idem, Distant Reading, London 2013, p. 46. 
impressively called distant reading. ${ }^{11}$ The former seems to me to be functionally false, while I consider the latter mercilessly, cynically true. Taken together, they allow to see, firstly, the inevitably totalising character of world literature (understood as a discourse that programmes both the style of research, as well as the way of teaching literature), and secondly, its destructive influence on literary studies.

For Damrosch, world literature is an attempt at literary confrontation with the global modernity and research appreciation of the fact that literary texts circulate more and more frequently outside of their native culture. He uses the term elliptical refraction for a kind of transformed projection of what is most important in the literature of a nation, displayed - most often in translationin one of the global languages (more and more often in English) on a global or supra-local screen. Damrosch's argument is erudite, coherent, auto-critical, and self-limiting. For example, he clearly recognises the "technical" problems associated with the vast amount of competence needed to conduct reasonable research into world literature (the proposed solution is research teams). The functional fallacy of this thinking is a consequence of focusing attention on the change of meanings of texts subjected to refraction. In Damrosch's book, there is no satisfactory answer to the question about the principles of selection and change, about the policy of selection and the economy of competition, he simply asks about the consequences of refraction for the semantics of the text. For example, about what William Shakespeare means in Poland-but not about why Shakespeare is read in Poland and Jan Kochanowski is not read in England. In other words, Damrosch does not ask questions about the functioning of the global circulation of literature, he is not interested in inequality, which he apparently treats as natural or necessary. And yet the question of why Kochanowski is not an important poet for the English is not a banal one at all. The answer to it is banally simple, but asking oneself a question of this type often turns out to be too difficult.

Moretti's speculations do not show similar auto-criticism and self-restraint. The Italian literary scholar does not say that world literature is only a "mode of reading", he does not distance himself from the notion of a canon, etc. On the contrary, his deliberations clearly employ the "metaphysics of a two-headed calf", ${ }^{12}$ i.e. the interrelated notions of a system as a whole ("literary system",

11 "Marc Bloch once coined a lovely 'slogan' [...]: 'years of analysis for a day of synthesis' [...]. Years of analysis, other people's analysis, which Wallerstein's page synthesises into a system. Now, if we take this model seriously [...] in that case literary history will quickly become very different from what it is now: it will become 'second hand': a patchwork of other people's research". Ibidem, pp. 47-48.

12 See: S.I. Witkiewicz, Mr. Price, or, Tropical Madness; and, Metaphysics of a TwoHeaded Calf, transl. D.C. Gerould, London, New York 2002. Polish original: S.I. Witkiewicz, Metafizyka dwugłowego cielęcia: Sztuka w trzech aktach, in: idem: Dramaty, vol. II, ed. J. Degler, Warszawa 1998, pp. 131-204, notebook pp. 564-586. Incidentally, the action 
"one") and a hierarchy ("unequal"). This necessarily entails a diametrically opposite view to that taken by Damrosch of what a literary scholar interested in world literature actually does. In Damrosch, it was reading texts outside their original context (and most often translated into another language), searching for meanings, interpreting works "transplanted" to another culture/ cultures. In Moretti, who is not interested in text but in the whole literary system, there is no room to read literary texts-for the simple reason that there are too many of them.

From the perspective of a literary scholar who studies complicated relationships between two literatures: small (Polish) and even smaller (Lithuanian), Moretti's consent to not reading original literary texts is particularly shocking. According to Moretti, fruitful research on world literature is only possible "[...] without a single direct textual reading" ${ }^{13}$ i.e. without access to originals, in a way on the basis of secondary synthesis, i.e. based on syntheses of a narrower range, prepared by researchers of various national literatures.

It seems that both understandings of world literature are linked by an uncritical attitude towards the secondary literature on the subject, which, however, cannot be falsified without having direct access to the so-called primary bibliography (i.e. literary texts in original languages).

\section{The canon and the periphery}

A great illustration of the effects of evading questions about the selection policy and of implementing the postulate of non-reading (or reading only translations) is provided by the popular American compendium, intended, to all appearances, mainly for students of junior colleges and baccalaureate stud-

of this 1921 play takes place in Australia, and its origins are closely linked to the ambivalent attitude of European culture to the heritage of Verne-Fogg, or more precisely to a journey to the ends of the world. In 1914, Witkiewicz, as a draughtsman and photographer, set off with his friend Bronisław Malinowski on an anthropological research expedition to New Guinea. "The journey began on 9 June 1914 and led from London [what a coincidenceP.B.] through the English Channel to Calais, and from there by train via Paris to Toulon, where friends boarded the British ship Orsova. Thus, they arrived to Colombo, Ceylon, on 29 June. For two weeks they visited the island and on 11 July, on the board of the ship Orontes they sailed to the Australian port Freemantle". J. Degler, [notes], in: S.I. Witkiewicz, Dramaty..., op.cit., p. 565. Eventually, Malinowski reached New Guinea alone; when Witkiewicz learnt about the outbreak of the Great War, on 5 September 1914 in Sydney he boarded a ship sailing back to Europe.

13 F. Moretti, op.cit., p. 48. Emphasis-F.M. 
ies: the Gale Contextual Encyclopedia of World Literature. ${ }^{14}$ I use this biographically oriented encyclopaedic synthesis to read the description of world literature as a canon of world literature, and thus test the theory in action. I chose this particular encyclopaedia not because I consider it to be a particularly characteristic book, but because it gave me the impression of a fairly average publication of this kind. I can easily point to both far better ${ }^{15}$ and far worse ${ }^{16}$ studies of the same type. Ultimately, it is not because this particular book is sufficiently representative of the whole trend discussed, but because it exists, is read, and is similar to many others. Therefore, even if one should not judge the entirety of research on world literature on the basis of this single item, it is certainly possible and necessary to point out the mechanisms that are threatening to literatures of the world, clearly visible in this book, and genetically connected with thinking about literature à la Phileas Fogg.

The Gale Contextual Encyclopedia consists of four thick volumes, more than 1800 pages, 1750 entries on the history of literature, an abundance of indices and chronological tables - the whole world, all world literature, beginning with Gilgamesh, in your hand. Experienced teachers of literature supervised the edition of the whole undertaking; the professional achievements of Anne M. Hacht in particular inspire respect. ${ }^{17}$ The scale and ambitions of the whole project are described in a concise Introduction:

The Gale Contextual Encyclopedia of World Literature is a resource for students who seek information beyond the simple biographical details of an author's life or a brief overview of the author's major works. This book is designed to offer a comprehensive view of how an author's work fits within the context of the author's life, historical events, and the literary world. This allows for a greater understanding of both the author's work and the cultural and historical environment in which it was created.

The Gale Contextual Encyclopedia of World Literature is divided into entries, each focused on a particular writer who has made significant contributions to world literature. $[\ldots]$ This book is best used not just to locate the facts of a writer's life

14 Gale Contextual Encyclopedia of World Literature, vol. I-IV, eds. A.M. Hacht, D.D. Hayes, Detroit 2009.

15 For example, Lexikon der Weltliteratur: biographisch-bibliographisches Handwörterbuch nach Autoren und anonymen Werken; fremdsprachige Autoren, ed. G. von Wilpert, Stuttgart 2004.

16 For example, World Authors 1900-1995, ed. C. Thompson, New York, Dublin 1999.

17 She is the author of many extremely popular textbooks, such as Poetry for Students: Presenting Analysis, Context and Criticism on Commonly Studied Poetry (thirty four editions in the twenty-first century), Literary Themes for Students: Examining Diverse Literature to Understand and Compare Universal Themes (twenty eight editions in the twenty-first century), Shakespeare for Students: Critical Interpretations of Shakespeare's Plays and Poetry (ten editions in the twenty-first century). See A.M. Hacht's profile: http:// worldcat.org/identities/lccn-nr2003005473/ (access: 12.08.2019). 
and work, but as a way to understand the social, literary, and historical environment in which the writer lived and created. ${ }^{18}$

Originally, I was going to look at what the creators of the encyclopaedia in question have to say about Lithuanian and Polish literature, that is, the national literatures I deal with professionally. Soon, however, I had to alter my plans. The encyclopaedia does not contain any entry devoted to Lithuanian literature or-which I immediately checked-Latvian literature. The absence of the writers of these two Baltic nations is nothing special. If, on the basis of the encyclopaedia's table of contents, a map of the world were to be reconstructed as a map of presence, it would rather turn out to be a map of absence. Among the first hundred writers included in the pages of the encyclopaedia, there are as many as forty authors writing in English, ${ }^{19}$ there are seventeen women, and finally there are more than thirty non-European writers $^{20}$, of whom only six do not or did not write in a European language ${ }^{21}$. These data may of course be insufficiently precise, among the names starting with letters other than A or B the proportions may be slightly different. However, the balance of power is obvious from the very beginning but also expected. In the encyclopaedia analysed, the largest languages of the world, including European ones, are absolutely dominant: apart from English, also Spanish, French, and Portuguese. The smallest language represented in the first hundred writers was probably Danish (as the language of Andersen's work and part of Karen Blixen's output).

No wonder that none of the Lithuanian (or Latvian) writers "made significant contributions". However, the "Baltic question" does not boil down to the absence of these two small literatures of small languages in the encyclopaedia (by the way, they are not "small" at all, which will be discussed later). If, for example, someone interested in Latvian literature (geographically and culturally close to Lithuanian literature) had read this book, he would have discovered that despite the absence of Latvian writers, the word "Latvian" still appears in it. Once, in an entry on Wystan Hugh Auden! In the frame presenting his "literary and historical contemporaries" Mark Rothko was mentioned as a "Latvian-born Jewish-American painter". ${ }^{22}$

Latvian culture has thus take the place of Aouda (or Gustave Flaubert's Kuchuk Hanem): it appears indirectly and only for a moment, deprived of its own voice, as an exotic attraction and a passive, momentary medium

18 Gale Contextual Encyclopedia..., vol. I, op.cit., p. xxi.

19 An approximate number; some of the authors included in the encyclopaedia used more than one language in their work.

20 An approximate number, some of the authors included in the encyclopaedia, e.g. Jews, spent part of their lives in Europe.

21 Two are Hebrew writers, two are Japanese, the fifth is Arabian, the sixth is Chinese.

22 Gale Contextual Encyclopedia..., vol. I, op.cit., p. 123. 
of self-confirmation sought by Mr Europe. On the same principle, Lithuania appears in this book e.g. in the entry devoted to Graham Greene, who "travelled widely and wrote works set in locales as disparate as Hanoi and Havana, Liberia and Lithuania, Mexico and Malaysia". ${ }^{23}$ This tasteful alliteration is an insult to the local cultures of Cuba, Liberia, Lithuania, Malaysia, Mexico, and Vietnam, and I see in it a direct equivalent of the colonial machismo of Flaubert and Verne. Therefore, if we asked the authors of the book whether Baltic literatures are a part of the world literature system, we would get a definite affirmative answer, because every literature in the world, by definition, should be a part of world literature understood as a whole. Even if these literatures do not contribute anything to this whole, they are part of a system based on inequalities, as they are affected by the centre. The encyclopaedia analysed faithfully reflects all colonial and quasi-colonial, violent dependencies. I see in it a practical confirmation of what Damrosch did not seem to want to admit, but what Moretti openly confirmed - namely that world literature is a concept based on the rhetoric of domination, exclusion, and conquest.

At first glance, Polish literature is in a better position than Baltic literatures as it is represented by no fewer than five writers. However, the second glance - at the names of these writers - makes us revise this judgment, since these five include: Witold Gombrowicz, ${ }^{24}$ Czeslaw [sic!-P.B.] Mi$\operatorname{losz}^{25}$ [sic!-P.B.], Tadeusz Rozewicz ${ }^{26}$ [sic!-P.B.], Bruno Schulz, ${ }^{27}$ and Wislawa [sic!-P.B.] Szymborska. ${ }^{28}$ Four spelling errors in five names are by no means all the mistakes and simplifications to be found in these entries. For example, the alphabetically first Gombrowicz is presented there as the author of Ivona, Princess of Burgundia [sic!-P.B.]. Ivona, contrary to the information put in brackets next to the title, namely "(1957)", ${ }^{29}$ is not, however, a post-war drama, as it was published in 1938 in the "Skamander" magazine (1957 was the date of its stage premiere).

The discussion of Czeslaw [sic!-P.B.] Milosz [sic!-P.B.] and Bruno Schulz's literary output is relatively less controversial. Among the simplifications characteristic of a concise encyclopaedic note, errors similar to those indicated above (and below) include only the definition of Miłosz's book The Native Realm: A Search for Self-Definition as "a lyrical recreation of the landscape and culture of Milosz's [sic!-P.B.] youth" and no comment on the difference between the title of the translation and the original (Rodzinna Europa

\footnotetext{
23 Ibidem, vol. II, p. 745.

24 Ibidem, pp. 718-720.

25 Ibidem, vol. III, pp. 1077-1080.

26 Ibidem, pp. 1332-1336.

27 Ibidem, vol. IV, pp. 1383-1385.

28 Ibidem, pp. 1526-1529.

29 Ibidem, vol. II, p. 717.
} 
is literally Family Europe and not The Native Realm; in addition, the Polish original does not have a subtitle). ${ }^{30}$ The way in which Schulz's death is presented may also raise fundamental doubts. A juxtaposition of information from the Key facts section, always placed just below the name ("NATIONALITY: Polish" ${ }^{\prime 1}$ ) with a terse account of the circumstances in which the writer lost his life (" $[\ldots]$ he was fatally shot by a soldier in Nazi-occupied Drohobycz in 1942"32) may suggest that Schulz was accidentally killed during the war, while he died as a Jew, not as a Pole, and was one of the millions of Holocaust victims.

The case of Tadeusz Rozewicz [sic! - P.B.] is much worse. His main works mentioned in the book include: "Anxiety (1947)[,] Collected poems (1957)[,] The Card Index (1960)[,] Birth Rate (1968)[,] White Marriage (1974)". From the perspective of a Polish literature historian, the choice of these titles is simply grotesque. His popular volume, in fact initiating the whole Polish post-war poetry (Anxiety, or originally Niepokój) is accompanied by a broad presentation of Różewicz's poetic output to date, that is simply a retrospective book (Collected poems are Wiersze zebrane published by Wydawnictwo Literackie in Kraków) and three dramas, with Birth Rate in which the key subtitle (Przyrost naturalny: Biografia sztuki teatralnej, literally Natural growth. The biography of dramatic art) was not included. ${ }^{33}$ From the whole of the writer's later work, the main part of the entry mentions only another drama entitled The Trap $(\text { Putapka })^{34}$. For example, lyrical books from the turn of the twenty-first century - undoubtedly innovative and outstanding, and at the same time shocking as a reading and existential experience - have not been even mentioned.

Among Wislawa [sic!-P.B.] Szymborska's most important achievements the encyclopaedia mentions three premiere books: Calling Out to the Yeti, or Wołanie do yeti, Salt, or Sól, People on a Bridge, or Ludzie na moście, and two retrospective books: View with A Grain of Sand, or Widok z ziarnkiem piasku and the 1981 English translation of Sounds, Feelings, Thoughts by Magnus J. Krynski and Robert A. Maguire. ${ }^{35}$ Just like in the case of Różewicz, the randomness of this selection and over-representation of Szymborska's early works are striking.

\footnotetext{
30 Ibidem, vol. III, p. 1079

1 Ibidem, vol. IV, p. 1383.

32 Ibidem, p. 1384.

33 Ibidem, vol. III, p. 1332.

34 Ibidem, p. 1334.

35 Ibidem, vol. IV, p. 1526.
} 


\section{Elliptical refractions, or a road with no return}

I point out the spelling errors to publishers of the encyclopaedia in question, which result from the fact that specifically Polish diacritical marks are not used, because I believe that this issue goes far beyond a plain simplification of notation. I will reject the charge of pettiness with the following question: how many mistakes in the notation of one surname can be passed in silence? One? Two? How about three? The authors of the encyclopaedia, technical editors, publishers, proof-readers, etc. at least once managed to make as many as three spelling mistakes in a single word and not correct them at any stage of preparing the book for print (an enterprise, let us admit it, not easy): "Anna Swieszczynska" ${ }^{36}$ mentioned in the entry on Wisława Szymborska is, as one should guess, the excellent (and - due to her pacifism, feminism, and sensuality—very "worldly") Polish poet, Anna—let me correct all the three spelling errors in her surname-Świrszczyńska.

However, not the errors of the notation alone are of central significance here, even though they are irritating. It is about the cause that deeply underlies them. In order to grasp it, to see that spelling mistakes are not caused simply by the lack of Polish fonts (anyway, in the era of electronic editing this would be an extremely naive explanation), we should above all else put these mistakes together with other types of errors, which I briefly listed above. These were various simplifications and inconsistencies, such as excessive focus on a certain period of artistic life (the case of Różewicz and, to a lesser extent, Szymborska), an unfortunate chronological suggestion (Ivona by Gombrowicz), a too risky summary of a book (The Native Realm) or biography (Schulz's death), etc., and so on. And yet the very choice of Polish writers is a misunderstanding: they all represent the twentieth century, ${ }^{37}$ and the absence of Jan Kochanowski or Adam Mickiewicz, mentioned earlier, cannot be justified by any reasons based on merit or content. ${ }^{38}$

Observed together with the Baltic literatures and cultures (Lithuanian and Latvian), specifically absent from the pages of the encyclopaedia, these mistakes turn out to be distortions which, let Damrosch forgive me, I cannot name more accurately than with his classic metaphor. There are hardly any clearer examples of elliptical refraction than the silences and deformations of names, profiles, and literary hierarchies that occurred in this book when crossing the border between Eastern European locality and global world literature (and

\section{Ibidem, p. 1527.}

37 Besides, the entire book under discussion is overly focused on the literature of the nineteenth and twentieth centuries.

38 By the way, the spelling of the names of these two classic authors of Polish literature would not have caused the authors any difficulties, which they had experienced with Świrszczyńska or "Slomczynski", i.e., in fact, Słomczyński, mentioned just next to her. 
I have no reason to believe that in the case of other literary peripheries it is any better). In my opinion, the reason for the distortions in the image of Polish artists is primarily the specific character of the reception of their writing presented in the encyclopaedia (this, of course, also applies to the representatives of other peripheral national literatures, whose contribution to the whole turned out to be so clear from the perspective of the centre of this whole that they deserved separate entries).

This uniqueness can best be observed in the example of Tadeusz Różewicz. Even a superficial analysis of the secondary bibliography included in the text devoted to him ${ }^{39}$ clearly proves that this list not only serves as a useful reading guide for those interested, but is also a list of sources of knowledge used by the authors of the encyclopaedia on Różewicz's writing, which is probably complete or almost complete! There is no mention of Kartoteka rozrzucona (The scattered file) (the world premiere of 1992, publ. 1997), because they used a monograph of Różewicz's dramatic output available on the American market wkich was published in $1991 .^{40}$ The over-representation of poetic works from before 1976 is directly connected with the fact that the selection of Różewicz's poetry in English was published this very year. ${ }^{41}$ The lack of any specific information about the poet's works after 1990 (although he wrote and published masterpieces for at least two more decades and died in 2014) should be explained by the fact that the bibliography contains only one text from after 1991. What is more, it is - for an unknown reason-a short review of the London edition of Szymborska's poems, in which Różewicz is mentioned twice, but only in brackets (notably, again as Rozewicz). ${ }^{42}$ It seems that the authors of these entries simply did not read Różewicz in the original, nor any of the most important studies on his work (and these are in Polish), thus putting into practice the anti-reading ideals of Moretti a few years before they were published. ${ }^{43}$

39 Ibidem, vol. III, pp. 1335-1336. This bibliography contains, of course, only texts in English.

40 See: H. Filipowicz, A Laboratory of Impure Forms: The Plays of Tadeusz Różewicz, New York 1991. In the encyclopaedia, the name of the writer in the subtitle is consistently without Polish diacritic marks.

${ }^{41}$ See: T. Różewicz, Survivor, and Other Poems, transl. and with an introduction by M.J. Krynski, R.A. Maguire, Princeton, NJ 1976. In the encyclopaedia, the name of the writer in the bibliographic reference is consistently without Polish diacritic marks.

42 See: T. Halikowska-Smith, The Poetry of Wonderment (Wisława Szymborska: Poems New and Collected 1957-1997. London: Faber, £14.99), "Poetry Magazines" 2000, no. 15 , p. $46-49$.

43 I am also quite sure that the authors of the encyclopaedia, working on entries about other Polish-language writers, did not read their works and were satisfied with texts that discussed them. If they knew them, most probably the note by Czesław Miłosz that pertains to the very essence of their activities and that is contained in Nieobjęta ziemia (1984) would 
The indicated elliptical refractions prove that the reception of Polish literature in the case of the authors of the entries in question had a completely passive and mediated character (surprisingly similar to the specific lack of reception of Baltic literatures). They have inherited a certain quantum of information and have limited themselves to passing it on. The inevitable inflation of the value of knowledge thus conveyed entails deformations that must take place in the process of informing (teaching) about world literature designed in this way. Firstly, these include unavoidable distortions of facts (in this case names); secondly, accidental reinterpretations caused by the chaotic selection and hierarchisation of inherited information (Różewicz as a dramatist, Schulz as a Pole, etc.); thirdly, the impossibility of falsifying sources, checking information, whose value is unverifiable due to the absolute inaccessibility of original texts. The result is precisely the errors listed above-which are the more frequent and striking the more peripheral the mother culture of the authors and works subjected to elliptical refraction is.

This analysis reveals a dangerous paradox in the practical (cognitive and educational) application of the theoretical construct, which is the concept of world literature. Implemented in practice, it probably turns out to be the first style of research in the history of literary studies, which - at least in some cases - departed from the model, which from the very beginning provided intellectual balance and a chance for development to literary studies. The unprecedented freedom of conceptualisations, often risky, heretical, iconoclastic, and openly creationary, is balanced in this model by a constantly repeated gesture of return ad fontes, that is to original literary texts, which are a guarantee of security and continuity of discipline. The strategic renouncement of this possibility, i.e. limiting oneself to translations or not reading source texts at all, means that deterioration is inevitable! Specialists educated on this encyclopaedia will not be able to improve it, even if they are best prepared in terms of methodology, because without direct access to the texts of Schulz's short stories or Gombrowicz's novels, they will never be able to know more than what is contained in the encyclopaedia. Without a repeated return to sources, both the refractive and elliptical nature of world literature, understood as a canon and as a literary discourse, will inevitably intensify. Old mistakes will

not escape their attention and they would have had enough intellect, courage, and humility to, having read it, relate it to themselves - people who, admittedly, do not write poems, but books about poems, encyclopaedias of world literature: "In order to write a wise poem, one needs to know more than what the poem expresses. Consciousness precedes any means of expression. And this regret that in the memory of people we remain more stupid, than we actually were in our moments of sharp understanding". C. Miłosz, Niewyrażone, in: idem, Wiersze wszystkie, Kraków 2011, p. 798. Emphasis-P.B. Translation-K.S. 
mount up with new ones, the dominance of the English-speaking centre will become increasingly clear, and the fate of Baltic literature will be shared by other peripheries. ${ }^{44}$

In this sense, world literature, understood both as a discourse and as a research and educational project, is puzzlingly similar to the non-places described by Marc Augé (who creatively developed Michel de Certeau's ideas), especially such as airports, supermarkets and, above all, motorways:

Main roads no longer pass through towns, but lists of their notable featuresand, indeed, a whole commentary - appear on big signboards nearby. In a sense the traveller is absolved of the need to stop or even look. [...] The landscape keeps its distance, but its natural or architectural details give rise to a text, sometimes supplemented by a schematic plan when it appears that the passing traveller is not really into a position to see the remarkable feature drawn to his attention, and thus has to derive what pleasure he can from the mere knowledge of its proximity.

Motorway travel is thus doubly remarkable: it avoids, for functional reasons, all the principal places to which it takes us; and it makes comments on them. [...] those who pass [...] may pass by again, [...] so that an abstract space, one they have regular occasion to read rather than see, can become strangely familiar to them over time, much as other, richer people get used to the orchid-seller at Bangkok Airport, or the duty-free shop at Roissy I. ${ }^{45}$

The motorways, Augé notes, falsify the world by making the places near to which they run and of which they inform in a schematic and concise manner inaccessible, offering an illusion of the experience of the source. The analysed literary discourse does the same with the texts of novels or poems: it falsi-

44 This danger is clearly visible in the MA programme for world literature offered by the University of Warwick (https://warwick.ac.uk/fac/arts/english/postgraduatestudies/ world-literature/ [access: 12.08.2019]). The logic of choosing an example is similar to that of The Gale Contextual Encyclopedia. I quoted a random study programme; after closer examination it turned out that there are examples that fit my thesis more or less than this one. Again, however, it is not a question of whether the study curriculum analysed is perfectly representative, but that it exists. It is dominated by English-language literatures: English and American, while the whole picture is complemented by translations. My attention was drawn to the course entitled Petrofiction: Studies in World Literature. In the syllabus, eighteen writers are mentioned by name: Upton Sinclair, John McGrath, Ken Saro-Wiwa, Abdelrahman Munif, Nawal El-Saadawi, George Miller, Cormac McCarthy, China Miéville, Ghassan Kanafani, Sheena Wilson, Stephen King, Brian Aldiss, Tim Gatreaux, Joanna Kavenna, Alain Mabanckou, Robin Yassin-Kassab, Mohammed Hasan Alwan and Rose Tremain, twelve of them write/wrote in English, five in Arabic, one in French, and all of them will obviously be read in translations. It is clear how little to say a graduate of the world literature studies will have about the literary richness of the world.

45 M. Augé, Non-Places: An Introduction to Supermodernity, transl. J. Howe, London, New York 2008, pp. 78-79. 
fies literary reality, rendering literatures of the world about which it informs through ellipsis and refraction inaccessible, and offering an illusion of a reading-like experience of them.

World literature is similar to the non-places of our times also in a different, much more important way. Even if Augé does not write about this, there is a specific characteristic common to highways, airport departure halls, and supermarkets: all these spaces regulate and restrict the freedom of movement of people in various ways, preventing or at least significantly hindering their independent deviation from the imposed route. On a motorway, one must not turn back or leave the road spontaneously, the airport has prohibitions and restrictions governing directions of movement related to passport clearance, customs and security control, as well as the phase of travel (separate or partly separate spaces for arriving and departing passengers), in a supermarket one should not exit through the entrance or enter crossing the cash desk line, etc. What is important, the desired behaviour of travellers or customers is enforced by an appropriately designed infrastructure. Something similar can be observed in the practice of teaching world literature. It abscises the students of this style of literary studies from direct contact with many texts, making it impossible to "turn back", that is to verify secondary literature with the sources. The discursive "architecture" of world literature has been designed to prevent its adepts from moving back or turning back, or even turning aside, beyond what is translated into English. In other words, world literature too frequently turns out to be a non-philology: even if today it is still practised by competent philologists-comparatists, who specialise in literature of a specific language or languages, their successors will be deprived of such competences. The refractoriness and ellipticity of this discourse will inevitably intensify, the silent peripheries of the system ("one and unequal") will expand, and various inaccuracies and errors in the characteristics of exotic writers and texts will mount up. This is because Phileas Fogg has always been interested in only one place - the one from which he set off, that is, the one to which he is heading by the shortest possible route: London, the West, his own self. The discourse of world literature ensures that the reader, while travelling around the world, never leaves the centre.

\section{Many worlds, many literatures}

The inequalities, which Damrosch seems to ignore and which do not disturb Moretti at all, are an obvious fact. There is no denying that there are older and younger literatures, written and oral literatures, literatures of languages spoken by hundreds of millions of people and literatures of languages spoken by only hundreds or even tens of individuals. Should literary studies respect 
or counteract these inequalities? A reading of classic works on world literature $^{46}$ seems to indicate that they all accept these inequalities as rather natural and focus on the functioning of literary texts in the global context of these inequalities.

The refractive and elliptical character of the discourse of world literature means that its canons consist of writers who create in only a few dozen languages (according to The Gale Contextual Encyclopedia, there are only forty such languages)! Meanwhile, the number of languages in the world is currently estimated at around 7,000 - ethnologue.com gives the exact number of $7,111,{ }^{47}$ while in 2013 , according to the same source, there were 7,105 languages.$^{48}$ Of course, the accuracy of these data is suspiciously high, especially given the political dimension of the difference between a dialect and an autonomous language. The astonishing upward trend, which can be seen by comparing data from a few years ago with that of today (six more languages), can indeed be explained in part by political changes (e.g. the Montenegrin language ${ }^{49}$ ). Additionally, new languages, that is, languages not yet described by Western linguistics (the first best example of such a discovery being the Koro language, used in the Indian state of Arunachal Pradesh, ${ }^{50}$ first noticed by the West only in $2008^{51}$ ) are still being "discovered". All things considered, it is difficult to fully trust such accurate figures, but it is impossible to question their value as estimation. On the one hand, we have about 7,000 languages in the world, which "usually have rich literary traditions", 52 while on the other hand, world literature canon consists of texts written in only forty of them (which is slightly more than $0.5 \%$ ).

A huge majority of these ca. 7,000 languages are on the verge of extinction. If all the world's languages were to be sorted by the number of native speakers,

46 See for example: P. Casanova, The World Republic of Letters, transl. M. DeBevoise, Cambridge, MA 2004; T. D'haen, The Routledge Concise History of World Literature, London 2012.

47 https://ethnologue.com/guides/how-many-languages (access: 2.08.2019).

48 Cf. Ö. Dahl, The "Minor Language” Perspective, in: Major versus Minor? Languages and Literatures in a Globalized World, ed. T. D'haen, Amsterdam, Philadelphia 2015, p. 15.

49 See the declaration of the Montenegrin PEN Club in autumn 2015: http://montenet. org/language/pen-decl.htm (access: 2.08.2019).

50 https://glottolog.org/resource/languoid/id/koro1316 (access: 2.08.2019).

51 See: D. Morrison, "Hidden" Language Found in Remote Indian Tribe, https:// www.nationalgeographic.com/news/2010/10/101005-lost-language-india-science/ (access: 2.08.2019).

52 Ö. Dahl, op.cit., p. 23. 
from Chinese to the Yámana language spoken by one person, ${ }^{53}$ the median would be 10,000 ! This means that every second language in the world is spoken by less than 10,000 people. ${ }^{54}$ Native speakers of these 3,500 languages, which are below the median, represent only about $0.1 \%$ of humanity, while as much as $50 \%$ of humanity speaks only the twenty four largest languages. ${ }^{55}$ Dahl also reports that only 393 languages (or about $5.5 \%$ of the whole pool) have over a million users and that they are spoken by $94 \%$ of humanity. ${ }^{56}$

I believe that the disproportions that have been identified here should be absolutely the most important issue in the contemporary study of world literature. It is not a question of merely reconstructing their origins - they are obvious - but of consciously reorienting this discourse, as well as the research and teaching governed by it, so that they cease to be an inert extension of the colonial residuum of exclusion and speaking on someone's behalf, that is the hard core of the "one and unequal" global system of literature.

World literature should be treated as a plurale tantum, an endless multitude of languages, i.e. worlds. ${ }^{57}$ The proposed reorientation of discourse would pose at least two fundamental challenges to world literature studies. One of them would be the so-called small literatures, which are, admittedly, rather not visible from the perspective of world literature today, but which have their own rich tradition of writing, their own institutions, as well as a relatively stable publishing and reading market. The refractive and elliptical discourse of "one and unequal" world literature reinforces the threat of their progressive, multi-faceted marginalisation brought by globalisation.

The other challenge, much more serious, is the hundreds and thousands of really small literatures, most often never written down, which are- together with their languages - on the brink of extinction. Interdisciplinary rescue research on these dying worlds should be the most important reason for the existence of all those centres of literary studies that have the ambition to speak of world literature.

53 T. Collins, 91-year Old Woman from Chile..., https://www.dailymail.co.uk/sciencetech/article-7107263/How-ancient-language-South-America-extinct.html (access: 12.08.2019).

54 Ö. Dahl, op.cit., pp. 15-16.

55 J. Loh, D. Hermon, Biocultural Diversity: Threatened Species, Endangered Languages, Zeist 2014, p. 23, http://d2ouvy59p0dg6k.cloudfront.net/downloads/biocultural_ report_june_2014.pdf (access: 2.08.2019).

56 Ö. Dahl, op.cit., p. 15.

57 "Behind the cycle of the hours and the outstanding features of the landscape, what we find are words and languages: the specialized words of the liturgy, of 'ancient ritual', in contrast to the 'song and chatter', of the workshop; and the words, too, of all who speak the same language, and thus recognize that they belong to the same world. Place is completed through the word [...]". M. Augé, op.cit., pp. 62-63. 
Unfortunately, I have no doubt that the proposal to reorient the world literature discourse in such a way as to stimulate global protection of literary diversity is even less effective than analogous calls for the protection of biodiversity. Phileas Fogg was, is and will be a Londoner ever on the shortest route to London. He lacks the audacity of Ulysses.

Translated by Kaja Szymańska

\section{Literature}

Alighieri D., La Divina Comedia, a cura di T. Di Salvo, Bologna 1991.

Alighieri D., The Divine Comedy. Inferno, transl. H.W. Longfellow, https://wyomingcatholic.edu/wp-content/uploads/dante-01-inferno.pdf (access: 12.08.2019).

Augé M., Non-Places: An Introduction to Supermodernity, transl. John Howe, London, New York 2008.

Casanova P., The World Republic of Letters, transl. Malcolm DeBevoise, Cambridge, MA 2004.

Collins T., 91-year Old Woman from Chile..., https://www.dailymail.co.uk/sciencetech/article-7107263/How-ancient-language-South-America-extinct.html (access: 12.08.2019).

Dahl Ö., The "Minor Language” Perspective, in: Major versus Minor? Languages and Literatures in a Globalized World, ed. Theo D'haen, Amsterdam, Philadelphia 2015, pp. 15-23.

Damrosch D., What Is World Literature?, Princeton, NJ 2003.

D'haen T., The Routledge Concise History of World Literature, London 2012.

Gale Contextual Encyclopedia of World Literature, , vol. I-IV, eds. A.M. Hacht, D.D. Hayes, Detroit 2009.

Filipowicz H., A Laboratory of Impure Forms: The Plays of Tadeusz Różewicz, New York 1991.

Halikowska-Smith T., The Poetry of Wonderment (Wisława Szymborska: Poems New and Collected 1957-1997. London: Faber, £14.99), "Poetry Magazines" 2000, no. 15, p. 46-49.

Lagercrantz O., Odyseusz, in: idem, Od piekiet do raju: Dante i „Boska Komedia”, transl. A.M. Linke, Warszawa 1970, pp. 60-71.

Lagercrantz O., Odysseus, in: idem, Från helvetet till paradiset: En bok om Dante och hans komedii, Stockholm 1964, pp. 64-76.

Lexikon der Weltliteratur: biographisch-bibliographisches Handwörterbuch nach Autoren und anonymen Werken; fremdsprachige Autoren, ed. G. von Wilpert, Stuttgart 2004. 
Loh J., Hermon D., Biocultural Diversity: Threatened Species, Endangered Languages, Zeist 2014, pp. 22-26, http://d2ouvy59p0dg6k.cloudfront.net/downloads/biocultural_report_june_2014.pdf (access: 2.08.2019).

Miłosz C., Niewyrażone, in: idem, Wiersze wszystkie, Kraków 2011, p. 798.

Moretti F., Conjectures on World Literatures, in: idem, Distant Reading, London 2013, pp. 43-62.

Morrison D., “Hidden” Language Found in Remote Indian Tribe, https:/www.nationalgeographic.com/news/2010/10/101005-lost-language-india-science/ (access: 2.08.2019).

Różewicz T., Survivor, and Other Poems, transl. and with an introduction by M.J. Krynski, R.A. Maguire, Princeton, NJ 1976.

Verne Jules, Le tour du monde en quatre-vingts jours, Paris [1874].

Witkiewicz Stanisław I., Metafizyka dwugłowego cielęcia: Sztuka w trzech aktach, in: idem: Dramaty, vol. II, ed. Janusz Degler, Warszawa 1998, pp. 131-204, notebook pp. 564-586.

Witkiewicz Stanisław I., Mr. Price, or, Tropical Madness; and, Metaphysics of a TwoHeaded Calf, transl. Daniel C. Gerould, London, New York 2002.

World Authors 1900-1995, ed. C. Thompson, New York, Dublin 1999.

\section{Websites}

https://bankofengland.co.uk/monetary-policy/inflation (access: 12.08.2019).

https://ethnologue.com/guides/how-many-languages (access: 2.08.2019).

https://glottolog.org/resource/languoid/id/koro1316 (access: 2.08.2019).

http://montenet.org/language/pen-decl.htm (access: 2.08.2019).

https://youtube.com/watch?v=zT8cOuLgU30 (access: 12.08.2019).

https://warwick.ac.uk/fac/arts/english/postgraduatestudies/world-literature/ (access: 12.08.2019).

http://worldcat.org/identities/lccn-nr2003005473/ (access: 12.08.2019). 